\title{
FENOMENA DISFEMISME DALAM KARTUN ANAK PADA PERTELEVISIAN INDONESIA
}

The Phenomenon of Dysphemism in Children's Cartoons on Indonesian Television

\author{
Lelly Dwi Anjani dan Bakdal Ginanjar \\ Universitas Sebelas Maret \\ bakdalginanjar@staff.uns.ac.id
}

Naskah Diterima Tanggal 14 Oktober 2019-Direvisi Akhir Tanggal 23 April 2021_Disetujui Tanggal 1 Juni 2021 doi: https://doi.org/10.26499/rnh.v10i1.1787

\begin{abstract}
Abstrak
Dalam tulisan ini dikaji penggunaan disfemisme dalam tayangan kartun anak pada pertelevisian Indonesia yang dikategorikan berbahaya serta hati-hati menurut KPAI dan KPI. Permasalahan dalam tulisan ini difokuskan pada pembahasan jenis disfemisme yang digunakan. Penelitian ini berjenis deskriptif kualitatif. Data penelitian ini berupa kalimat yang mengandung disfemisme. Sumber data penelitian ini adalah tayangan kartun anak "Spongebob Squarepants" "Crayon Shinchan", dan "Little Krishna" yang diambil dari tayangan televisi dan YouTube. Metode penyediaan data yang digunakan adalah metode simak dengan teknik rekam dan teknik catat. Metode analisis data yang digunakan adalah metode agih dengan teknik bagi unsur langsung, teknik lesap, dan teknik ganti. Hasil analisis data disajikan dengan metode informal. Berdasarkan hasil analisis data, disimpulkan bahwa jenis disfemisme dalam tayangan kartun anak pada pertelevisian Indonesia berupa 1) perbandingan manusia dengan hewan yang secara konvensional dianggap memiliki perilaku tertentu, 2) istilah atau julukan yang berasal dari organ tubuh yang ditabukan, efluvia tubuh (bau atau sekresi), dan perilaku seksual, 3) julukan atau sapaan disfemistik yang diambil dari karakter fisik yang terlihat sehingga dianggap seolah menjadi orang yang abnormal, 4) kutukan dan julukan yang menggunakan istilah dari abnormalitas mental atau penyakit jiwa, 5) disfemisme sexist, racist, speciesist, classist, ageist, dan -IST lainnya yang berfungsi sebagai penghinaan, dan 6) istilah penghinaan atau tidak hormat yang menyerukan penghinaan pada karakter yang dituju.
\end{abstract}

Kata-Kata Kunci: disfemisme, jenis disfemisme, kartun anak

\begin{abstract}
This paper examines the use of dysphemism in children's cartoon shows in Indonesian television which are categorized as dangerous and cautious according to KPAI and KPI. The issue of this paper is focused on discussing the types of dysfemism used. This research is a descriptive qualitative type. The data of this research are sentences containing dysphemism. The data source of this research is the children's cartoon show Spongebob Squarepants, Crayon Shinchan, and Little Krishna taken from television and Youtube shows. The method of providing data is done by referring to the record and record techniques. The method of data analysis is done by the method of distribution with techniques for direct elements, fade techniques, and dressing techniques. The results of data analysis are presented by informal methods. Based on the results of data analysis, it was concluded that the type of dysfemism in children's cartoon shows in Indonesian television is in the form of 1) a comparison between humans and animals that are conventionally considered to have certain behaviors, 2) term or nickname derived from taboo body organs, body effluvia (odor or secretion), and sexual behavior, 3) nickname or dysphemistic greetings taken from physical characters that are seen so that it is considered to be an abnormal person, 4) curses and nicknames that use the term from mental abnormalities or mental
\end{abstract}


illness, 5) sexist, racist, speciesist, classist, ageist and otherIST dysfemism that function as insults, and 6) the term insult or disrespect that calls insult to the intended character.

Keywords: dysphemism, type of dysphemism, cartoon children

How to Cite: Anjani, Lelly Dwi dan Bakdal Ginanjar. (2021). Fenomena Disfemisme dalam Kartun Anak pada Pertelevisian Indonesia. Ranah: Jurnal Kajian Bahasa. 10(1). 1-12. doi: https://doi.org/10.26499/rnh.v10i1.1787

\section{PENDAHULUAN}

Penggunaan disfemisme di berbagai kalangan masyarakat setakat ini dapat diketahui sangat marak. Dalam hal ini, disfemisme merupakan ungkapan dengan konotasi kasar yang digunakan pembicara serta pendengar (Allan \& Burridge, 2006). Dalam sebuah kajian yang dilakukan terhadap anak-anak di Gampong Ulee Lhat, Montasik, Aceh Besar, disimpulkan bahwa ungkapan tersebut ditengarai tidak hanya cenderung digunakan oleh kalangan masyarakat dewasa, tetapi juga sudah fasih digunakan oleh anak-anak ketika mereka berkomunikasi dengan orang tua, masyarakat, dan teman sebayanya, baik di lingkungan keluarga, masyarakat, sekolah, maupun tempat pengajian (Nisak et al., 2018).

Fenomena tersebut menunjukkan betapa dinamisnya penggunaan disfemisme di kelompok umur anak-anak. Penyebab dari situasi tersebut adalah perkembangan sosial budaya, media elektronik, media massa, dan media sosial di masyarakat secara global yang membawa dampak pada perkembangan kebahasaan anak-anak (Azmi, 2014). Lebih lanjut, diungkapkan bahwa anak-anak memiliki sifat yang lebih pasif dalam berinteraksi dengan media elektronik, terutama televisi. Hal itu terjadi karena anak-anak belum memiliki kemampuan untuk memilah sesuatu yang benar atau salah. Mereka cenderung mengikuti sesuatu yang dilihatnya di televisi sehingga berimbas pada sikap, pola pikir, dan perilaku, tak terkecuali bahasa yang muncul dalam tayangan televisi.

Penelitian yang mengangkat masalah disfemisme dalam berbagai ranah penggunaan di masyarakat telah dilakukan oleh peneliti sebelumnya. Salah satunya adalah dalam ranah media cetak, elektronik, serta online yang dapat dilihat pada penelitian (Suraya, 2013), (Sabatini, 2016) (Sulistri, 2017), (Juwita \& Wahyudi, 2018) (Riyanto et al., 2018), (Gapur et al., 2019), (Matondang \& Purnanto, 2020), (Sitanggang et al., 2020), (Iswara \& Sastaparamitha, 2020), (Rahmawati \& Ariesta, 2020), (Olimat, 2020), (Darmawan \& Muhaimi, 2020), (Hasyim et al., 2020), (Safitri et al., 2020), (Zakiri, 2020), dan (Muhammad, 2021). Namun, belum terdapat kajian yang secara khusus menyoroti permasalahan disfemisme, khususnya pada ranah kelompok anak-anak sehingga hal itu menjadi celah kajian yang layak untuk dianalisis secara lebih jauh.

Salah satu produk dari tayangan televisi untuk anak-anak adalah kartun anak. Menurut Kamus Besar Bahasa Indonesia (KBBI) Daring, yang dimaksud dengan kartun adalah 'film yang menciptakan khayalan gerak sebagai hasil pemotretan rangkaian gambar yang melukiskan perubahan posisi'. Kartun juga dapat diartikan sebagai gambar dengan penampilan yang lucu dan berkaitan dengan keadaan yang sedang berlaku, terutama mengenai politik.

Kemasan kartun yang lucu membuat anak-anak menyukainya. Sementara itu, penggunaan bahasa berkonotasi kasar banyak ditemukan dalam tayangan kartun anak pada pertelevisian Indonesia saat ini. Hal itu diperkuat dengan adanya tindakan dari Komisi Perlindungan Anak Indonesia (kpai.go.id, 2014) yang mendaftarkan tiga buah tayangan kartun yang dianggap berbahaya dan dua buah tayangan kartun berkategori hati-hati. Tiga kartun yang dianggap berbahaya meliputi "Tom \& Jerry" (ditayangkan di ANTV, RCTI, dan Global TV), "Little Krishna" (ditayangkan di ANTV), dan "Bima Sakti" (ditayangkan di ANTV). Sementara itu, kartun anak yang dikategorikan hati-hati adalah "Spongebob Squarepants" (ditayangkan di Global TV) dan "Crayon Shinchan" (ditayangkan di RCTI). 
Kartun-kartun tersebut memperoleh teguran dan penarikan penayangan di Indonesia karena kontennya dianggap tidak sesuai untuk anak-anak, yaitu banyak ditemukan tindak kekerasan di dalamnya, baik kekerasan yang berbentuk verbal maupun nonverbal. Kartunkartun tersebut merupakan kartun asing dari negara Amerika Serikat, India, dan Jepang yang ditayangkan dengan mengalihbahasakan dari bahasa sumber ke bahasa Indonesia. Adanya pengalihan bahasa tersebut ternyata tidak menutup kemungkinan masih ditemukan kata-kata yang mengandung muatan bahasa berkonotasi kasar. Hal itu dipandang akan memberikan dampak serius terhadap perkembangan bahasa anak.

Sehubungan dengan hal itu, dalam tulisan ini akan dibahas permasalahan tentang bagaimana tipe disfemisme yang terdapat dalam tayangan kartun anak yang dikategorikan berbahaya dan hati-hati. Dengan adanya deskripsi jenis disfemisme, dapat diketahui tipe disfemisme yang muncul dalam tayangan kartun anak sehingga dapat digunakan secara lebih aplikatif. Dengan demikian, ketepatan pengalihbahasaan dalam tayangan kartun diharapkan akan membawa dampak lebih positif bagi perilaku berbahasa dan sosial anak.

\section{LANDASAN TEORI}

Disfemisme merupakan ungkapan dengan konotasi kasar yang digunakan oleh pembicara serta pendengar (Allan \& Burridge, 1991). Ungkapan kasar yang digunakan dapat digantikan dengan ungkapan netral atau eufemisme. Lebih lanjut, dijelaskan bahwa disfemisme merupakan kebalikan dari eufemisme dan dapat disebut sebagai tabu. Disfemisme muncul sebagai akibat dari rasa takut, ketidaksukaan, kebencian, dan penghinaan. Disfemisme memiliki karakteristik yang sama seperti persekongkolan. Ekspresi disfemisme dapat berupa ungkapan mengutuk, sebutan, atau komentar yang bersifat menghina dan melukai perasaan orang lain (Duda, 2011).

Disfemisme digunakan untuk mengungkapkan kemarahan dan frustrasi. Dalam hal ini, disfemisme adalah sebuah kata atau ungkapan dengan arti tambahan yang menyerang seseorang (Allan \& Burridge, 2006). Terkait dengan itu, disfemisme bertujuan ofensif kepada penerima atau penonton, konsep itu sendiri, atau denotatum (Ruiz, 2017). Di sisi lain, disfemisme digunakan oleh pembicara dengan fungsi untuk membicarakan seseorang atau hal yang membuat kecewa dan mengganggu mereka, untuk menunjukkan sikap tidak setuju, untuk mencela, untuk menghina, untuk merendahkan, untuk melepaskan emosi (meredakan kekecewaan atau amarah), dsb. (Allan \& Burridge, 2006).

Disfemisme dapat dibagi atas delapan tipe (Allan \& Burridge, 2006). Pertama, bermacam istilah tabu yang digunakan untuk memaki, mengejek, menyakiti, dan memaki. Tipe ini dapat dicontohkan muncul dalam kebudayaan Barat, yaitu dengan penyebutan organ tubuh yang digunakan untuk buang air besar atau kecil serta aktivitas-aktivitas yang dilakukan oleh organ tersebut, termasuk zat-zat yang dihasilkan oleh organ tersebut. Di pihak lain, disebutkan bahwa dalam kebudayaan Barat istilah tabu dapat muncul pada hal-hal tentang agama, kriminalitas, prostitusi, cacat fisik dan mental, dan narkotika (Salinger's \& Karjalainen, 2002).

Kedua, makian serta serapah yang cabul. Memaki dikatakan sebagai disfemisme karena ungkapan makian bertujaun untuk menyakiti atau menghina objek tertentu, bisa orang atau halhal di seputarnya. Dalam kebudayaan Barat, makian ini termasuk disfemisme juga jika mengambil istilah yang berkaitan dengan penghujatan nama Tuhan, bisa juga dalam hal penggunaan istilah cabul dan serapah. Lebih lanjut, motif serapah sebagai makian terdiri atas sepuluh jenis: religius, skatologis, genital, seksual, sodomi, ibu, prostitusi, masturbasi, binatang, dan kematian (Ljung, 2006). Tipe ini dalam kebudayaan Jawa dapat muncul dari ungkapan yang berkaitan dengan tindakan atau keadaan yang berkenaan dengan berbicara, makan, minum, mati, pergi, dan bagian-bagian tubuh tertentu (Wijana, 2008). 
Ketiga, perbandingan manusia dengan hewan yang secara konvensional dianggap memiliki perilaku tertentu. Disfemisme jenis ini biasanya menggunakan disfemisme namanama hewan. Disfemisme tersebut diambil dari beberapa karakteristik hewan yang menonjol serta pandangan masyarakat terhadap tampilan atau perilaku seekor hewan yang kemudian secara metaforis dikaitkan dengan tampilan atau perilaku manusia. Contohnya adalah memanggil seseorang dengan sebutan babi, sapi, anjing, kutu, tikus, banteng, kambing, kera, keledai, ular, dll. Nama hewan betina biasanya digunakan untuk penamaan seorang wanita. Misalnya, sebutan kucing memiliki arti perempuan yang ganas atau kasar, sebutan sapi umumnya menunjukkan wanita yang tidak disukai karena sangat lamban dan berkonotasi gemuk. Hal itu dikaitkan dengan sapi yang memiliki ukuran tubuh yang besar. Sementara itu, terdapat beberapa nama hewan yang biasanya digunakan untuk penamaan seorang pria. Misalnya, sebutan anjing menunjukkan seseorang yang jahat, sebutan rubah menunjukkan pria licik, sebutan banteng untuk pria besar, atau sebutan babi untuk seseorang yang jorok (hal itu sebanding dengan perilaku yang dimiliki babi dalam kehidupan nyata). Oleh karena itu, perilaku menghina bersubjek tabu.

Keempat, istilah atau julukan yang berasal dari organ tubuh yang ditabukan, efluvia tubuh (bau atau sekresi), dan perilaku seksual. Disfemisme jenis ini biasanya menggunakan istilah dari organ tubuh yang tabu, efluvia tubuh (seperti kotoran),dan perilaku seksual(seperti penjilat pantat, pelacur, dll). Selain itu, menghina seseorang dengan kata penis dan pelacur, serta menyebut homoseksualitas untuk seorang pria yang berhubungan seksual dengan laki-laki lain juga termasuk dalam disfemisme ini. Sementara itu, dalam bahasa Inggris hanya terdapat istilah tertentu yang berfungsi sebagai julukan, umpatan, dan istilah penyalahgunaan disfemisme jenis ini. Contohnya adalah kata-kata yang dipelajari untuk organ sex, micturition, defecation (SMD) dan efluvia pada umumnya, seperti kata bajingan, kotoran, keparat, dan penjilat.

Kelima, julukan atau sapaan disfemistik yang diambil dari karakter fisik yang terlihat sehingga dianggap seolah menjadi orang yang abnormal. Disfemisme jenis ini biasanya menggunakan istilah yang berasal dari keadaan fisik seseorang yang tidak kompeten atau istilah yang berasal dari nama-nama penyakit. Istilah atau julukan tersebut dapat menjadi disfemisme rasis dan julukan disfemistik yang ditolak oleh pembicara. Contohnya adalah menyebut seseorang dengan sebutan gendut, botak, pendek, dan homoseksualitas. Menyebut seseorang dengan sebutan lemah dianggap mengabaikan kecakapan fisik seseorang. Sebutan lumpuh dianggap sebagai seseorang yang secara fisik tidak kompeten dalam beberapa hal. Hal itu sama dengan pertanyaan "Apakah Anda buta?" yang dapat menjadi disfemistik tentang persepsi visual seseorang atau memanggil seseorang penderita kusta, yang berarti menjadi orang yang dijauhi. Beberapa penyakit juga dapat digunakan dalam disfemisme ini, seperti cacar, penyakit pes, lepra, dan kolera. Oleh karena itu, metafora penyakit juga muncul dalam penghinaan rasis.

Keenam, kutukan dan julukan yang menggunakan istilah dari abnormalitas mental atau penyakit jiwa. Disfemisme jenis ini menggunakan semua istilah penghinaan yang mencerminkan ciri negatif yang melekat pada subnormalitas mental seseorang sehingga membutuhkan eufemisme. Contohnya adalah ungkapan orang bodoh, konyol, cacat mental, orang gila, dan dasar hina. Ungkapan, seperti dia brengsek sampai saat ini juga dianggap sebagai keterbelakangan mental serta tidak normal secara fisik. Disfemisme keabnormalan mental yang tersirat dalam penghinaan, seperti maniak, gila, dan sinting telah dianggap sebagai istilah pujian di kalangan tertentu. Meskipun perilaku antisosial mereka dicela oleh masyarakat pada umumnya, mereka mengadopsi julukan seperti itu sebagai suatu kehormatan akibat dari pemberontakan mereka terhadap norma sosial.

Ketujuh, disfemisme sexist, racist, speciesist, classist, ageist, dan kata berakhiran -ist lainnya yang berfungsi sebagai penghinaan. Disfemisme jenis ini biasanya digunakan untuk menghina atau mengejek seseorang dengan menggunakan disfemisme sexist, racist, speciesist, 
classist, dan ageist. Misalnya, anak-anak mengubah nama seseorang untuk menghina atau menggodanya, seperti Tina Fritz berubah menjadi Freena Tits. Gejala itu merupakan jenis disfemisme -ist awal. Sementara itu, disfemisme rasis untuk mencontohkan disfemisme -ist secara umum adalah kelompok manusia yang memiliki sebuah istilah dalam bahasa mereka untuk menghina kelompok lain (etnis lain) seperti ungkapan camel jockey untuk orang Arab dan ungkapan negro untuk orang berkulit hitam.

Kedelapan, istilah penghinaan atau tidak hormat yang menyerukan penghinaan terhadap karakter yang dituju. Disfemisme jenis ini biasanya digunakan untuk menghina seseorang dengan menggunakan ungkapan, seperti bajingan, pembunuh ,orang sinting, norak, homo, orang kolot, kakek tua, penggerutu, kutu buku, banci, orang bodoh, sampah,jorok, pelacur, anak jalang, gelandangan, pengecut, dan penyihir. Selain itu, ungkapan-ungkapan tersebut banyak yang berasal dari organ tubuh yang tabu, efluvia, dan perilaku seksual. Ungkapan tua yang konyol bersifat ageist dan disfemistik. Penghinaan akan meningkat jika ungkapan tua merupakan istilah yang tabu.

Terdapat dua motif penggunaan ungkapan disfemisme dalam memperbincangkan suatu topik (Allan \& Burridge, 2006). Motif pertama adalah untuk menghina atau menistakan citra orang yang menjadi sasaran. Motif kedua adalah pemaksimalan suatu luka atau sakitnya seseorang kepada orang yang dituju. Oleh karena itu, motif kedua tersebut dapat melahirkan kemarahan, ketidaksukaan, penghinaan, ejekan, dan frustrasi. Di sisi lain, disfemisme difungsikan sebagai seruan karena kaget atau terganggu, sumpah, menyetujui atau takmenyetujui, mengutuk, menghina/mencaci/menista, melecehkan, menegaskan suatu ketidaksukaan, menekankan suatu seruan, menekankan suatu pertanyaan, dan memaki (Ljung, 2006).

\section{METODE PENELITIAN}

Penelitian ini merupakan penelitian kualitatif yang bersifat deskriptif. Data yang digunakan dalam penelitian ini berupa kalimat yang mengandung disfemisme. Sementara itu, sumber data dalam penelitian ini meliputi tayangan kartun anak "Spongebob Squarepants", "Crayon Shinchan", dan "Little Krishna" yang diambil dari televisi dan YouTube, baik yang masih ditayangkan maupun yang sudah tidak ditayangkan. Sampel tayangan kartun anak yang digunakan tersebut merupakan tayangan kartun anak yang dikategorikan berbahaya, yaitu berasal dari kartun "Spongebob Squarepants" yang tayang pada Desember 2018 - Januari 2019. Sementara itu, tayangan kartun anak yang berkategori hati-hati menurut Komisi Perlindungan Anak Indonesia (KPAI) dan Komisi Penyiaran Indonesia (KPI) berasal dari "Crayon Shinchan" episode 41-76 dan Little "Krishna" episode "The Charge of the Monster Horse", "Challenge of the Brute", "The Mystery of the Vanishing Sheep", "Assault of the Lethal Bird", "Witch Trap", "The Horror Cave', "The Vicious Whirlwind", dan "The Attack of the Serpent King".

Metode penyediaan data yang digunakan dalam penelitian ini berupa metode simak dengan teknik rekam dan teknik catat. Data yang terkumpul ditranskripsi, kemudian diidentifikasi dan diklasifikasikan.

Data yang telah terklasifikasi dianalisis dengan metode agih, lalu dilanjutkan dengan bagi unsur langsung, teknik lesap, dan teknik ganti (Sudaryanto, 2015). Hasil dari analisis data dalam penelitian ini akan disajikan dengan metode informal, yaitu metode penyediaan hasil analisis data dengan menggunakan kata-kata (Sudaryanto, 2015). 


\section{PEMBAHASAN}

Berdasarkan analisis yang dilakukan, ditemukan disfemisme sebanyak 243 data yang terbagi ke dalam 6 tipe. Keenam tipe tersebut secara berurutan terdiri atas (1) perbandingan manusia dengan hewan yang secara konvensional dianggap memiliki perilaku tertentu, (2) istilah atau julukan yang berasal dari organ tubuh yang ditabukan, effluvia tubuh (bau atau sekresi), dan perilaku seksual, (3) julukan atau sapaan disfemistik yang diambil dari karakter fisik yang terlihat sehingga dianggap seolah menjadi orang yang abnormal, (4) kutukan dan julukan yang menggunakan istilah dari abnormalitas mental dan penyakit jiwa, (5) disfemisme sexist, racist, speciesit, classist, ageist, dan -ist lainnya yang berfungsi sebagai penghinaan, dan (6) istilah penghinaan atau tidak hormat yang menyerukan penghinaan pada karakter yang dituju. Deskripsi setiap tipe disfemisme tersebut dapat diuraikan sebagai berikut.

\section{Disfemisme Perbandingan Manusia dengan Hewan yang secara Konvensional Dianggap Memiliki Perilaku Tertentu}

Disfemisme jenis ini biasanya menggunakan nama-nama hewan. Disfemisme tersebut diambil dari beberapa karakteristik hewan yang menonjol serta pandangan masyarakat terhadap tampilan atau perilaku seekor hewan yang kemudian secara metaforis dikaitkan dengan tampilan atau perilaku manusia. Hal itu ditemukan dalam Data (1-3).

(1) Kau itu sama liciknya dengan para monyet, Krishna! Tentu saja mereka menurutimu.

(2) Kalian adalah kecoak yang sulit disingkirkan!

(3) Tentu, biarkan aku yang melakukan semua pekerjaan, sementara kau hanya duduk seperti gorila gemuk!

Dalam Data (1-3) ditemukan tiap-tiap kata, yakni monyet, kecoak, dan gorila sebagai disfemisme dalam tayangan kartun anak. Kata monyet dalam Data (1) merupakan nomina. Monyet menurut KBBI Daring berarti 'kera berbulu keabu-abuan dan berekor panjang, tetapi kulit muka, telapak tangan serta telapak kakinya tidak berbulu'. Kata kecoak dalam Data (2) menurut KBBI Daring berarti 'lipas'. Lipas adalah 'serangga bersayap yang dapat terbang, biasanya berada di rumah-rumah, terutama di tempat kotor'. Sementara itu, gorila dalam Data (3) menurut KBBI Daring sebagai 'primata terbesar dari Afrika, berwarna hitam, dan banyak memakan makanan nabati'. Ketiga kata tersebut dianggap berkonotasi kasar karena mengacu pada diri seseorang, yakni ditandai dengan penggunaan kata kau dalam Data (1), kalian dalam Data (2), dan kau dalam Data (3).

Ketiga kata tersebut merupakan wujud disfemisme yang muncul dalam kartun anak. Hal itu disebabkan ketiganya digunakan untuk menyamakan karakteristik seseorang yang dianggap memiliki kesamaan dengan karakter atau perilaku dari hewan monyet yang licik, kecoak yang menjijikkan dan sulit disingkirkan, dan gorila dengan fisik yang gemuk dan sifat pemalas.

Anggapan bahwa monyet memiliki sifat licik dilatarbelakangi oleh pandangan dari sebagian masyarakat yang menganggap bahwa monyet sering bersikap curang terhadap kawanannya, terutama ketika mereka memperoleh makanan. Para monyet sering berebut makanan dengan bersikap licik terhadap kawanannya guna mendapat makanan yang banyak. Dalam sebagian besar cerita rakyat pun hewan ini lebih banyak digambarkan memiliki sifat licik dalam perilakunya terhadap makhluk lainnya. Budaya masyarakat yang meyakini bahwa monyet memiliki sifat licik, sering kali dikaitkan dengan sifat manusia yang bersikap curang dan serakah. Sementara itu, kecoak dipandang sebagai hewan yang menjijikkan karena habitatnya selalu berada di tempat yang dianggap kotor oleh manusia. Akibatnya, manusia sering kali ingin menyingkirkannya. Di sisi lain, gorila dipandang sebagai hewan yang bertubuh gemuk dan malas untuk bergerak. Lebih lanjut, gorila dipandang pula secara fisik sebagai hewan yang buruk rupa. 


\section{Disfemisme Istilah atau Julukan yang Berasal dari Organ Tubuh yang Ditabukan, Efluvia Tubuh (Bau atau Sekresi), dan Perilaku Seksual}

Disfemisme jenis ini biasanya menggunakan istilah dari organ tubuh yang tabu, efluvia tubuh (seperti kotoran), dan perilaku seksual (seperti penjilat pantat, pelacur, dan lain-lain). Jenis ini ditunjukkan dalam Data (4-6).

(4) Aku tidak bisa keluar karena aku sudah ada di luar sini. Kalian pemakan bokong, buka matamu dan menangis yang keras!

(5) Halo, pria bau!

(6) Coba aku lihat apa saja yang ada dalam mulutnya. Napas baunya luar biasa, rambutnya terlihat asli, dia kotor. Emmm, bau busuk dan lihat pembuatan mekanisme rahangnya.

Disfemisme dalam Data (4--6) secara berurutan masing-masing terdapat pada frasa pemakan bokong, pria bau, dan bau busuk. Kata pemakan menurut KBBI Daring berarti 'sesuatu yang dipakai untuk makan atau hewan yang memakan'. Sementara itu, bokong menurut KBBI Daring berarti 'pantat, belakang, atau pinggul'. Berdasarkan kedua definisi tersebut, dapat dikatakan yang dimaksud dengan pemakan bokong dalam Data (2) adalah hewan serta orang yang memakan pantat atau bokong. Frasa tersebut dianggap berkonotasi kasar karena mengacu pada diri seseorang, yakni ditandai dengan penggunaan kata kalian pada kalimat tersebut. Selain itu, frasa tersebut digunakan untuk memanggil atau memberi julukan kepada seseorang dengan menggunakan istilah dari organ tubuh yang ditabukan, yakni berupa kata bokong.

Selanjutnya, kata bau menurut KBBI Daring berarti 'sesuatu yang dapat ditangkap oleh indera pencium (seperti anyir, harum, dan busuk)'. Kata tersebut dalam Data (5) dan (6) mengandung konotasi kasar karena ditujukan kepada diri seseorang yang ditandai dengan adanya satuan lingual yang mengacu pada seseorang, yakni kata pria dalam Data (5) dan kata ganti -nya pada (6). Selain itu, kata bau dalam Data (5) sekaligus digunakan untuk menjuluki atau memanggil seseorang yang tubuhnya dianggap berbau sesuatu yang tak sedap.

Sehubungan dengan itu, tindakan memanggil atau memberikan julukan kepada seseorang dengan menggunakan istilah dari organ tubuh yang ditabukan dipandang sebagai ungkapan yang tidak hormat dan dapat melukai perasaan orang tersebut. Selain itu, ketika frasa atau bagian frasa dihilangkan atau diganti dengan satuan lingual lainnya dari Data (4-6), makna kalimat tersebut menjadi lebih bernuansa netral dan secara gramatikal dapat diterima seperti pada kalimat (4a-6a).

(4a) Aku tidak bisa keluar karena aku sudah ada di luar sini. Kalian, buka matamu dan menangis yang keras!

(5a) Halo, pria.

(6a) Coba aku lihat apa saja yang ada dalam mulutnya. Napas baunya luar biasa, rambutnya terlihat asli, dia kotor. Emmm, bau tidak sedap dan lihat pembuatan mekanisme rahangnya.

Disfemisme Julukan atau Sapaan Disfemistik yang Diambil dari Karakter Fisik yang Terlihat sehingga Dianggap Seolah Menjadi Orang yang Abnormal

Disfemisme jenis ini biasanya menggunakan istilah yang berasal dari keadaan fisik seseorang yang tidak kompeten atau istilah yang berasal dari nama-nama penyakit. Istilah atau julukan tersebut dapat menjadi disfemisme rasis dan julukan disfemistik yang ditolak oleh pembicara. Jenis ini diperlihatkan dalam Data (7-9) berikut ini.

(7) Akhirnya si Nenek buruk rupa itu pun pulang ke rumahnya, Gary.

(8) Menyingkir dari jalanku, kepala lancip!

(9) Spongebob! Dengarkan aku, kepala botak! Kau menyakiti pendengaranku, aku sudah muak! 
Disfemisme dalam Data (7) berupa frasa si Nenek buruk rupa. Frasa ini merupakan frasa nomina dengan unsur disfemisme yang berpusat pada frasa buruk rupa. Buruk rupa menurut KBBI Daring berarti 'bertampang jelek'. Frasa buruk rupa dalam Data (7) dianggap sebagai frasa yang berkonotasi kasar karena mengacu pada diri seseorang, yakni ditandai dengan penggunaan kata si Nenek dan kata rupa yang berarti mengacu pada diri dari nenek tersebut. Sementara itu, disfemisme dalam (8) terdapat dalam frasa kepala lancip yang menunjukkan bagian kepala seseorang yang berbentuk tidak sebagaimana biasanya, tetapi berbentuk lancip

Tindakan memanggil seseorang dengan memberikan julukan berdasarkan karakter fisik yang dianggap buruk, yaitu buruk rupa merupakan ungkapan yang tidak sopan dan dipandang dapat melukai perasaan orang tersebut. Oleh karena itu, frasa buruk rupa pada kalimat (7) dianggap sebagai disfemisme. Selain itu, ketika frasa buruk rupa dihilangkan dari kalimat (7), makna kalimat tersebut menjadi lebih bernuansa netral seperti pada kalimat (7a). Demikian juga halnya dengan keadaan fisik seseorang yang dipandang memiliki kepala lancip dianggap tidak wajar/normal bagi sebagian masyarakat. Oleh karena itu, pemanggilan nama seseorang dengan julukan berdasarkan karakter fisik yang dianggap tidak normal itu merupakan ungkapan yang tidak hormat dan dapat melukai perasaan orang lain. Hal serupa terjadi pada ungkapan kepala botak dalam Data (9) yang diarahkan untuk menjuluki seseorang berdasarkan keadaan fisik yang seolah tidak normal sebagaimana orang yang dipenuhi rambut di kepalanya.

Ketiga frase terebut akan dapat dihilangkan kadar disfemismenya ketika sebagian atau keseluruhan satuan lingualnya dilesapkan. Dengan demikian, akan terbentuk kalimat (7a-9a) berikut ini yang bermakna lebih netral.

(7a) Akhirnya si Nenek itu pun pulang ke rumahnya, Gary.

(8a) Menyingkir dari jalanku! Menyingkir! Menyingkirlah!

(9a) Spongebob! Dengarkan aku! Kau menyakiti pendengaranku, aku sudah muak.

\section{Disfemisme Kutukan dan Julukan yang Menggunakan Istilah dari Abnormalitas Mental atau Penyakit Jiwa}

Disfemisme jenis ini menggunakan semua penghinaan yang mencerminkan ciri negatif yang melekat pada subnormalitas mental seseorang. Data (10-12) berikut ini menunjukkan disfemisme kutukan dan julukan yang menggunakan istilah dari abnormalitas mental atau penyakit jiwa.

(10) Kau akan menginterogasi blender? Kau gila!

(11) Masuklah ke dalam, kalian orang konyol! Kelas segera dimulai.

(12) Ow, waktuku tinggal setengah jam lagi dan idiot-idiot itu mengambil rumahku, itu artinya alat itu tidak akan menggangguku lagi.

Dalam Data (10) ditemukan disfemisme berbentuk frasa kau gila. Gila menurut KBBI Daring berarti 'sakit ingatan, sakit jiwa, tidak biasa, tidak sebagai mestinya, tidak masuk akal'. Frasa itu dianggap sebagai frasa yang berkonotasi kasar karena mengacu pada diri seseorang, yakni ditandai dengan penggunaan kata kau pada kalimat tersebut. Frasa itu juga digunakan untuk memberikan julukan kepada seseorang yang dianggap kurang akalnya. Sikap menginterogasi blender (benda mati) seperti yang ditunjukkan dalam Data (10) dianggap sebagai sikap yang tidak wajar bagi sebagian masyarakat sehingga orang yang melakukan sikap tersebut dianggap menjadi orang yang abnormal. Data (11) juga menunjukkan disfemisme dengan penggunaan ungkapan orang konyol. Konyol dalam KBBI Daring berarti 'tidak sopan, kurang ajar, agak gila, kurang akal, tidak berguna, dan si-sia'. Hal itu menunjukkan bahwa orang konyol dalam data tersebut adalah seseorang yang dipandang kurang akal sehingga memiliki sikap tidak sopan, kurang ajar, dan sedikit gila. Sementara itu, disfemisme dalam Data (12) muncul dari ungkapan idiot-idiot yang mengacu pada seseorang. Kata tersebut dalam KBBI Daring berarti 'taraf atau tingkat kecerdasan berpikir yang sangat rendah, daya pikir yang 
lemah sekali, atau tunagrahita'. Ungkapan itu digunakan untuk menyatakan kekesalan dengan cara menjuluki seseorang yang dianggap memiliki tingkat berpikir yang rendah.

Tindakan memberikan julukan melalui ketiga ungkapan itu dipandang sebagai tindakan yang tidak hormat dan dapat melukai perasaan orang lain. Itu karena ungkapan tersebut memiliki bentuk lain yang lebih halus untuk digunakan atau malah dilesapkan sama sekali seperti dalam (10a-12a) berikut ini.

(10a) Kau akan menginterogasi blender? Kau tidak masuk akal!

(11a) Masuklah ke dalam, kalian! Kelas segera dimulai.

(12a) Ow, waktuku tinggal setengah jam lagi dan mereka itu mengambil rumahku, itu artinya alat itu tidak akan menggangguku lagi.

Bentuk tidak masuk akal merupakan bentuk yang lebih halus daripada kata gila dalam konteks tersebut dan penggunaan bentuk tidak masuk akal pada (10a) membuat kalimat tersebut menjadi lebih bernuansa makna netral. Selain itu, bentuk tidak masuk akal dapat diterima sebagai hasil penggantian unsur gila dari kalimat (4) sehingga kalimat (4a) dapat diterima, baik secara gramatikal maupun secara leksikal. Sementara itu, ungkapan disfemisme dalam orang konyol dan idiot-idiot akan bermakna halus ketika keduanya dilesapkan sebagaimana pada (11a) dan (12a).

\section{Disfemisme Sexist, Racist, Speciesist, Classist, Ageist, dan -ist lainnya yang Berfungsi sebagai Penghinaan}

Disfemisme jenis ini biasanya digunakan untuk menghina atau mengejek seseorang dengan menggunakan disfemisme sexist, racist, speciesist, classist, ageist, dan -ist yang lainnya. Berikut ini merupakan data yang menunjukkan disfemisme sexist, racist, speciesist, classist, ageist, dan -ist lainnya yang berfungsi sebagai penghinaan.

(13) Ayo kita tinggalkan koki kelas bawah ini.

(14) Kau istri payah!

(15) Aku peringatkan kau Spongebob, simpan binatang kotor itu jauh dariku!

Disfemisme classist ditemukan dalam satuan frasa nominal koki kelas bawah dalam Data (13). Frasa tersebut memiliki unsur pusat disfemisme pada satuan kelas bawah. Kelas bawah menurut KBBI Daring berarti 'golongan orang yang menduduki tingkat sosial paling bawah dalam suatu masyarakat'. Frasa koki kelas bawah merupakan frasa yang berkonotasi kasar karena mengacu pada diri seseorang, yakni ditandai dengan penggunaan kata koki pada kalimat tersebut. Frasa tersebut digunakan untuk menghina seorang koki yang dianggap memiliki status sosial rendah. Tindakan merendahkan status sosial seseorang dengan memberikan julukan kelas bawah dianggap sebagai ungkapan yang tidak hormat dan dapat melukai perasaan orang tersebut. Oleh karena itu, diskriminasi berdasarkan tingkatan sosial yang ditunjukkan dalam data tersebut merupakan bentuk dari disfemisme classist.

Ungkapan istri payah dalam Data (14) digunakan untuk menghina seorang wanita yang dianggap memiliki kecakapan yang rendah. Julukan terhadap wanita itu dapat melukai seseorang dan ungkapan tersebut dikategorikan sebagai disfemisme sexist karena ditujukan berdasarkan gender. Sementara itu, ungkapan disfemisme binatang kotor dalam Data (15) termasuk disfemisme speciesist. Hal itu ditandai dengan pengacuan pada binatang tertentu yang ditempatkan sebagai makhluk yang rendah sebagaimana arti kotor dalam KBBI Daring sebagai sesuatu yang 'tidak bersih, kena noda, jorok, menjijikkan'.

Selanjutnya, ketika ketiga unsur frasa disfemisme tersebut dilesapkan atau diganti dengan satuan lainnya yang semakna, makna kalimat tersebut menjadi lebih bernuansa netral sebagaimana terlihat dalam $(13 a-15 a)$ berikut ini. 
(13a) Ayo kita tinggalkan koki ini.

(14a) Kau istri yang kurang cakap!

(15a) Aku peringatkan kau Spongebob, simpan binantang itu jauh dariku!

Pelesapan sebagian unsur disfemime dalam Data (13 dan 15) menjadi (13a dan 15b) dipandang dapat menghadirkan kalimat bernuansa makna netral dan secara gramatikal kedua kalimat dapat diterima. Di sisi lain, kadar disfemisme dalam ungkapan istri payah dapat dijadikan makna netral dengan mengganti unsur payah dengan kata lain yang semakna sebagaimana dalam (14a).

\section{Disfemisme Istilah Penghinaan atau Tidak Hormat yang Menyerukan Penghinaan terhadap Karakter yang Dituju}

Disfemisme jenis ini biasanya digunakan untuk menghina seseorang. Data (16-18) berikut ini merupakan data yang menunjukkan disfemisme istilah penghinaan atau tidak hormat yang menyerukan penghinaan terhadap karakter yang dituju.

(16) Larilah, pengecut! Tidak ada seorang pun yang bisa menghancurkan Bakasura. Tidak seorang pun!

(17) Halo, pecundang! Baiklah, kau yang ada di belakang.

(18) Mama ceroboh sekali! Jadi berantakan seperti ini.

Disfemisme dalam Data (16) terdapat pada penggunaan kata pengecut. Kata pengecut menurut KBBI Daring berarti 'penakut, munafik'. Ungkapan tersebut dianggap berkonotasi kasar karena mengacu pada diri seseorang, yakni ditandai dengan penggunaan kata larilah yang merupakan ungkapan memerintah kepada seseorang untuk berlari dan penggunaan ungkapan tidak ada seorang pun pada kalimat tersebut. Ungkapan itu digunakan untuk memberikan julukan kepada seorang penakut yang dianggap tidak memiliki keberanian. Sementara itu, kata pecundang dalam KBBI Daring berarti 'yang kalah, yang dikalahkan, orang yang menghasut, orang yang menipu'. Tindakan memanggil dengan julukan itu dianggap sebagai sikap yang tidak hormat karena merendahkan kehormatan orang lain. Demikian halnya dengan ungkapan ceroboh dalam Data (18) yang menunjukkan disfemisme. Ungkapan itu dalam KBBI Daring berarti 'tidak sopan, kasar, keji, sembrono, tidak berhati-hati, tidak cermat, tidak dipikirkan baik-baik, tidak rapi, tidak bersih'. Ungkapan tersebut menjadi disfemisme setelah dilekatkan pada figur seorang mama.

Ketiga ungkapan itu dapat dihilangkan kadar disfemismenya dengan cara melesapkan unsurnya atau menggantikannya dengan unsur lain yang semakna sebagaimana dalam (16a18a) di bawah ini.

(16a) Larilah! Tidak ada seorang pun yang bisa menghancurkan Bakasura. Tidak seorang pun!

(17a) Halo! Baiklah, kau yang ada di belakang.

(18a) Mama kurang berhati-hati. Jadi berantakan seperti ini.

Pelesapan ungkapan pengecut dan pecundang dalam (16a) dan (17a) menghasilkan kalimat yang bermakna lebih netral dibandingkan dengan Data (16) dan (17). Sementara itu, ungkapan disfemisme ceroboh dapat diganti dengan satuan kurang berhati-hati seperti dalam (18a) yang menjadikannya memiliki nuansa makna yang netral. Penggantian itu sekurangnya juga masih mempertahankan makna ungkapan sebelumnya.

Berdasarkan temuan data tentang jenis disfemisme, dapat digambarkan bahwa tipe disfemisme yang ditemukan dalam tayangan kartun anak pada pertelevisian Indonesia cenderung sesuai dengan teori disfemisme dari (Allan \& Burridge, 2006) serta (Ljung, 2006). Penggunaan disfemisme dalam tayangan kartun anak pada pertelevisian Indonesia yang dikategorikan berbahaya serta hati-hati menurut Komisi Perlindungan Anak Indonesia (KPAI) dan Komisi Penyiaran Indonesia (KPI) dilatarbelakangi oleh latar sosial serta budaya negara 
kartun anak tersebut berasal. Hal itu terjadi karena kartun anak tersebut merupakan tayangan yang diadopsi dari luar negeri, yakni dari negara Amerika Serikat, India, dan Jepang. Perbedaan sosial dan budaya antara negara Indonesia dan negara luar tersebut memunculkan adanya penggunaan ungkapan disfemisme dalam tayangan kartun anak pada pertelevisian Indonesia. Hal itu selaras dengan pernyataan bahwa semua kelompok manusia memiliki istilah hinaan dalam bahasa mereka untuk menghina kelompok lain (Allan \& Burridge, 2006).

Sehubungan dengan hal tersebut, penghilangan terhadap kata disfemisme yang hakikatnya merupakan terjemahan dari bahasa sumbernya juga tidak akan menyelesaikan masalah. Penghilangan tersebut hanya akan mendistorsi pesan yang ingin disampaikan dalam film tersebut. Untuk itu, diperlukan usaha pemanfaatan beberapa strategi yang tepat dalam penerjemahan (Putranti et al., 2018). Hal itu bertujuan agar masyarakat dapat tetap menikmati terjemahan yang berkualitas. Selain itu, hal itu dapat mengurangi dampak negatif penggunaan disfemisme. Untuk itu, diperlukan penerjemahan yang memperhatikan nilai rasa, bukan hanya terjemahan yang hanya mencari padanan kata. Hal itu selaras dengan pendapat (Meilasari et al., 2016). Terlebih lagi, dominasi jenis disfemisme yang terlihat terletak pada jenis istilah penghinaan atau tidak hormat yang menyerukan penghinaan pada karakter yang dituju. Efek dari hal tersebut salah satunya dapat dirasakan dalam kehidupan sehari-hari ketika banyak orang dengan mudah menghina orang lain.

\section{SIMPULAN}

Berdasarkan permasalahan yang telah dikaji dalam penelitian ini, disimpulkan bahwa tipe disfemisme yang ditemukan dalam tayangan kartun anak pada pertelevisian Indonesia berupa perbandingan manusia dengan hewan yang secara konvensional dianggap memiliki perilaku tertentu; istilah atau julukan yang berasal dari organ tubuh yang ditabukan, efluvia tubuh (bau atau sekresi), dan perilaku seksual; julukan atau sapaan disfemistik yang diambil dari karakter fisik yang terlihat sehingga dianggap seolah menjadi orang yang abnormal; kutukan dan julukan yang menggunakan istilah dari abnormalitas mental atau penyakit jiwa; disfemisme sexist, racist, speciesist, classist, ageist, dan -ist lainnya yang berfungsi sebagai penghinaan; dan istilah penghinaan atau tidak hormat yang menyerukan penghinaan pada karakter yang dituju.

\section{DAFTAR PUSTAKA}

Allan, K., \& Burridge, K. (1991). Euphemism \& dysphemism: Language used as shield and weapon. Oxford University Press New York.

Allan, K., \& Burridge, K. (2006). Forbidden words: Taboo and the censoring of language. Cambridge University Press. https://doi.org/10.1017/CBO9780511617881

Azmi, N. (2014). Dampak Media Televisi terhadap Prilaku Sosial Anak. Scientiae Educatia: Jurnal Pendidikan Sains, 3(2), 11-28.

Darmawan, I. N. P., \& Muhaimi, L. (2020). Dysphemism Lexical Items of Hate Speeches: Towards Education of Students for Political Correctness. 1st Annual Conference on Education and Social Sciences (ACCESS 2019), 242-245. https://doi.org/10.2991/assehr.k.200827.061

Duda, B. (2011). Euphemisms and dysphemism: In search of a boundary line. Circulo de Linguística Aplicada a La Comunicación, 45, 3. https://doi.org/10.5209/rev_CLAC.2011.v45.1

Gapur, A., Setia, E., \& Pujiono, M. (2019). Dysphemism Of Personal Pronoun Among Men's Character In Hiromasa Okushima's Comic Akira No 2. Jurnal Kata: Penelitian Tentang Ilmu Bahasa Dan Sastra, 3(2), 287-298.

Hasyim, K., Nurkamto, S., \& Santosa, R. (2020). Lexical Creation of Euphemism and Dysphemism in Online Media Text on Presidential Election 2019. BASA 2019: Proceedings of the Third International Seminar on Recent Language, Literature, and Local Culture Studies, BASA, 20-21 September 2019, Surakarta, Central Java, Indonesia, 342. https://doi.org/10.4108/eai.20-9$\underline{2019.2296891}$ 
Iswara, A. A., \& Sastaparamitha, N. N. A. J. (2020). The Form and Use of Dysphemism in Hoax. 4th International Conference on Language, Literature, Culture, and Education (ICOLLITE 2020), 28-34. https://doi.org/10.2991/assehr.k.201215.005

Juwita, N. P. R., \& Wahyudi, A. B. (2018). Penginovasian Bentuk Disfemisme pada Berita Online dan Relevansinya pada Bahan Ajar Bahasa Indonesia di SMP. Pena: Jurnal Pendidikan Bahasa Dan Sastra, 7(2), 33-45. https://doi.org/10.22437/pena.v7i2.5323

Ljung, M. (2006). Svordomsboken. Norstedts Akademiska Förlag, Stockholm.

Matondang, Z., \& Purnanto, D. (2020). A Meaning Component Analysis of Euphemism and Dysphemism in Indonesian Da'wah. International Journal of Linguistics, Literature and Translation, 3(9), 58-65.

Meilasari, P., Nababan, N., \& Djatmika, D. (2016). Analisis Terjemahan Ungkapan Eufemisme dan Disfemisme pada Teks Berita Online BBC. Prasasti: Journal of Linguistics, 1(2), 336-358. https://doi.org/10.20961/prasasti.v1i2.1030

Muhammad, I. (2021). Donald Trump's Use of Dysphemism for Mass Persuasion. Cairo Studies in English, 2020(1), 95-109. https://doi.org/10.21608/cse.2021.147190

Nisak, K., Bahry, R., \& Mahmud, S. (2018). Disfemisme Bahasa Aceh dalam Tuturan Anak-anak di Gampong Ulee Lhat, Montasik, Aceh Besar. JIM Pendididikan Bahasa Dan Sastra Indonesia, $3(2), 164-172$.

Olimat, S. N. (2020). Words as Powerful Weapons: Dysphemism in Trump's Covid-19 Speeches. $3 L$ : Language, Linguistics, Literature ${ }^{\circledR}, 26(3)$. https://doi.org/10.17576/3L-2020-2603-02

Putranti, S. D., Nababan, M. R., \& Tarjana, S. S. (2018). Sexual Language Translation: The Perspective of Teaching Polite English. Dinamika Ilmu, 18(1), 61-72. https://doi.org/10.21093/di.v18i1.1040

Rahmawati, L. E., \& Ariesta, W. (2020). Dysphemism in Online News Headlines: Student Demonstrations. PalArch's Journal of Archaeology of Egypt/Egyptology, 17(6), 908-915.

Riyanto, S., Sumarlam, S., \& Purianingtyas, A. R. (2018). Multiliteracy as The Dysphemism Handling Power of Elementary School Students. International Seminar on Recent Language, Literature, and Local Cultural Studies (BASA 2018).

Ruiz, R. S. (2017). Euphemism and Dysphemism During The War of The Spanish Succession (17101713): George Ridpath. Cuadernos de Investigación Filológica, 43, 7-31. https://doi.org/10.18172/cif.2959

Sabatini, F. (2016). Languaging gender and gendering language. Euphemism and dysphemism in dubbing. Lingue e Linguaggi, 17, 195-244.

Safitri, W., Sinaga, M., \& Septyanti, E. (n.d.). Perbandingan Penggunaan Disfemisme dalam Berita Kriminal Surat Kabar Tribun Pekanbaru dan Riau Pos. Jurnal Tuah: Pendidikan Dan Pengajaran Bahasa, 2(1), 32-42.

Sitanggang, M. A. P., Setia, E., \& Ganie, R. (2020). Dysphemism Used in Deadpool Movie Paper Title. Lire Journal (Journal of Linguistics and Literature), 4(2), 125-139. https://doi.org/10.33019/lire.v4i2.73

Sudaryanto. (2015). Metode dan Teknik Analisis Bahasa: Pengantar Penelitian Wahana Kebudayaan secara Linguistis. Diandra Primamitra.

Sulistri, A. (2017). Disfemis pada Tajuk Rencana dalam Surat Kabar Kedaulatan Rakyat. Bahasa Dan Sastra Indonesia-S1, 6(5), 640-649.

Suraya, S. (2013). Representasi Kekerasan Simbolik dalam Iklan Anak-anak. Komunikator, 5(01).

Wijana, I. D. P. (2008). Kata-kata kasar dalam bahasa Jawa. Jurnal Humaniora, 20(3), 249-256.

Zakiri, A. (2020). Penggunaan Eufemisme dan Disfemisme pada Buku Catatan Najwa Karya Najwa Shihab serta Implikasinya Terhadap Pembelajaran Bahasa Indonesia di SMA. Universitas Pancasakti Tegal. 